\title{
Acetic Acid Treatment of Commercial PtRu for Enhancement of Methanol Electrooxidation
}

\author{
Zirong $\mathrm{Li}^{1,2, *}$, Lei Bai ${ }^{2}$ and Baokang $\mathrm{Jin}^{1, *}$ \\ ${ }^{1}$ College of Chemistry \& Chemical Engineering, Anhui University, Hefei, Anhui, China, 230601 \\ ${ }^{2}$ College of Chemistry and Materials Engineering, Anhui Science and Technology University, \\ Bengbu, Anhui, China, 233000 \\ *E-mail: $\underline{\text { lizir@ahstu.edu.cn }}$
}

doi: $10.20964 / 2019.12 .34$

Received: 13 July 2019 / Accepted: 29 August 2019 / Published: 29 October 2019

Commercial carbon supported platinum-ruthenium alloy ( $\left.\mathrm{Pt}_{50} \mathrm{Ru}_{50}\right)$ was selected and employed as the target catalyst for the methanol electrooxidation. The performance $\mathrm{Pt}_{50} \mathrm{Ru}_{50} / \mathrm{C}$ in methanol oxidation could be easily enhanced by over 3 times after it was treated in the acetic acid under hydrothermal condition for 2 hours. The structure of this commercial carbon supported platinum-ruthenium alloy was well characterized by X-ray diffraction, transmission electron microscopy and X-ray photoelectron spectroscopy. In addition, the data from inductively coupled plasma optical emission spectrometry confirmed that a loss of $\mathrm{Pt}$ and $\mathrm{Ru}$ to some extent was observed and however, the molar ratio of $\mathrm{Pt}$ and $\mathrm{Ru}$ was kept as well as more fine particles were obtained. Our catalytic results suggested that the oxidation of ruthenium was one key point for the enhancement of catalytic ability, possibly due to the fact that after acetic acid treatment, more ruthenium oxides were presented, which could provide more active hydroxyl species and thus enhanced the catalytic ability. The dissolved oxygen in the acetic acid possibly led to the formation of Ru oxides and nearly had effect on the Pt. The present work expected that it could provide a new insight and facile method to increase the performance of commercial electrocatalysts for direct methanol fuel cell.

Keywords: platinum-ruthenium alloy; acetic acid; solvothermal treatment; methanol oxidation

\section{FULL TEXT}

(C) 2019 The Authors. Published by ESG (www.electrochemsci.org). This article is an open access article distributed under the terms and conditions of the Creative Commons Attribution license (http://creativecommons.org/licenses/by/4.0/). 